\title{
Phaseolin type and heat treatment influence the biochemistry of protein digestion in the rat intestine
}

\author{
Carlos A. Montoya ${ }^{1,2}$, Pascal Leterme ${ }^{2,3}$, Stephen Beebe ${ }^{4}$, Wolfgang B. Souffrant ${ }^{5}$, Daniel Mollé ${ }^{6}$ \\ and Jean-Paul Lallès ${ }^{1 *}$ \\ ${ }^{1}$ Institut National de la Recherche Agronomique, UMR1079 SENAH, F-35590 Saint-Gilles, France \\ ${ }^{2}$ Universidad Nacional de Colombia, Departamento de Produccion Animal, Carrera 32 Chapinero, Palmira (Valle), Colombia \\ ${ }^{3}$ Prairie Swine Centre, 2105 8th Street East, Saskatoon, SK, S7H 5N9, Canada \\ ${ }^{4}$ Centro Internacional de Agricultura Tropical, AA 6713, Cali, Colombia \\ ${ }^{5}$ FBN, Department of Nutritional Physiology 'Oskar Kellner', Wilhelm-Stahl-Allee 2, 18196 Dummerstorf, Germany \\ ${ }^{6}$ Institut National de la Recherche Agronomique, UMR1253 STLO, 65 rue Saint-Brieuc, 35042 Rennes Cedex, France
}

(Received 25 April 2007 - Revised 9 July 2007 - Accepted 10 July 2007)

The study aimed to investigate the in vivo digestion of Phaseolus vulgaris phaseolin types differing in their subunit pattern composition. Diets contained either casein as the sole source of protein or a mixture (1:1) of casein and pure Sanilac (S), Tendergreen (T) or Inca (I) phaseolin either unheated or heated. Rats were fed for $11 \mathrm{~d}$ with the experimental diets. Their ileal content and mucosa were collected and prepared for electrophoresis, Western blotting, densitometry and MS. Differences in digestion among native phaseolin types were observed for intact phaseolin at molecular weights (MW) of $47-50.5 \mathrm{kDa}$ and for an undigested fragment at MW of $19-21.5 \mathrm{kDa}$ in ileal digesta. In both cases, the concentration of these protein bands was lower for I phaseolin than for S or T phaseolin $(P<0.05)$. In the mucosa, the concentration of a protein band at MW of $20.5-21.5 \mathrm{kDa}$ was lower for S phaseolin as compared to T or I phaseolin $(P<0.001)$. The presence of phaseolin subunits and their fragments was confirmed by Western blotting. MS analysis revealed the presence of undigested $\alpha$ and $\beta$ subunit fragments from phaseolin and endogenous proteins (anionic trypsin I and pancreatic $\alpha$-amylase) in ileal digesta. Thermal treatment improved digestion $(P<0 \cdot 01$ ), acting on both dietary and endogenous protein components. In conclusion, this study provides evidence for differences in intestinal digestion among phaseolin types, S phaseolin being more resistant and I phaseolin more susceptible. These differences were affected by the origin of the phaseolin subunit precursor. Heat treatment enhanced phaseolin digestion.

Phaseolus vulgaris: Phaseolin type: Small intestine digestion: Rat

Common bean (Phaseolus vulgaris) is a staple food for rural populations in Latin America and Central Africa and represents a valuable source of protein, fibre, starch and minerals. Its consumption is also encouraged in industrialized countries thanks due to beneficial properties on health, such as reducing serum cholesterol levels and risks of CHD and diabetes ${ }^{1}$.

However, the nutritional value of bean protein is low, due to limited digestibility and marginal deficiency in sulphur-containing amino acids and tryptophan ${ }^{2}$. The storage globulin phaseolin represents about half of the total protein content of the seed and it is the main source of available methionine ${ }^{3}$. Contrary to other native legume proteins, phaseolin hydrolysis by pepsin and trypsin stops after a limited number of peptides have been cleaved off ${ }^{4,5}$. However, phaseolin digestion is markedly improved with thermal treatment ${ }^{6,7}$.

Many variants of phaseolin with different subunit patterns have been identified. Type I phaseolin lacks the largest $(52 \mathrm{kDa})$ subunit that the two major phaseolins Sanilac (S) and and Tendergreen $(\mathrm{T})$ have $^{8}$. Kami and Gepts ${ }^{9}$ found that the amino acid sequence of $\mathrm{S}$ phaseolin contained an additional methionine as compared to $\mathrm{T}$ phaseolin. Moreover, they suggested that the divergence of $\alpha$ and $\beta$ phaseolin genes predate the divergence between $\mathrm{S}$ and $\mathrm{T}$ phaseolins. Differences in subunit composition can affect protein hydrolysis among heat-treated S, T and Inca (I) phaseolin types $(58,71$ and $71 \%$, respectively ${ }^{10}$ ) and between micro-heterogeneous soyabean storage proteins ${ }^{11}$. Differences in ileal digestibility between the $\mathrm{S}$ and $\mathrm{T}$ phaseolins in pigs were observed ( 57 and $36 \%$, respectively ${ }^{12}$ ). However, in that study phaseolin was provided as whole common bean, thus confounding effects with other bean components.

Bean breeders would like to take advantage of differences in phaseolin composition for developing bean varieties with improved nutritional value. However, there is a need to better understand the kinetics of phaseolin hydrolysis in vivo for two reasons. First, proteolysis by pepsin and trypsin is limited. Therefore, differences in cleavage among phaseolin types could result in differential digestion and in absorbed profile of amino acids.

Abbreviations: I, Inca phaseolin; MW, molecular weight; S, Sanilac phaseolin; T, Tendergreen phaseolin.

* Corresponding author: Dr Jean-Paul Lallès, fax +33 (0)2 234850 80, email Jean-Paul.Lalles@rennes.inra.fr 
Second, the presence of undigested peptides in the lumen of the small intestine could increase secretions ${ }^{13}$. This would lead to more endogenous proteins (enzymes, antibodies and mucins) lost at the end of the small intestine, and therefore less amino acids available for maintenance and growth ${ }^{14,15}$. However, little information on the biochemical aspects of in vivo digestion among native and heat-treated phaseolin types exists.

The objectives of the present work were to study how three types ( $\mathrm{S}, \mathrm{T}$ and $\mathrm{I})$ of purified phaseolin were digested in the rat small intestine, and to characterize both the indigestible phaseolin and some endogenous proteins resulting from the intestinal digestion processes. The study was conducted on unheated and heated phaseolins, since heating was able to reveal difference in the in vitro hydrolysis among phaseolin types ${ }^{10}$.

\section{Experimental methods}

\section{Animals and diets}

The experiment was conducted in agreement with the guidelines of the National University of Colombia for care and use of laboratory animals ${ }^{16}$. Forty young adult Wistar female rats (generous gift of the Zoo of Cali) with an initial body weight of 255 (SD 14) g, were randomly allocated to one of the eight treatments and placed in individual metabolic cages (Tecniplast 150-300, Buguggiate, Italy) for the whole experimental period. The control diet contained casein as the sole protein source. Phaseolin-containing diets had half of protein supplied by casein and half supplied by the different types of purified phaseolin ${ }^{7}$. Crude protein content $(\mathrm{N} \times 6.25)$ for casein, and S, T and I phaseolin were 92, 96, 97 and $97 \%$, respectively. These were incorporated into the diets either untreated or after thermal treatment $\left(121^{\circ} \mathrm{C}\right.$ for $15 \mathrm{~min}$, $15 \mathrm{psi}$ ) (Table 1). The rats were fed the diets for $10 \mathrm{~d}$ after which they were killed ${ }^{7}$. Food intake was limited to $10 \mathrm{~g} / \mathrm{d}$ in order to limit food refusals ${ }^{7}$.

\section{Preparation of ileal digesta and mucosa}

Digesta and mucosa were sampled after the killing of the rats on day $11,3 \mathrm{~h}$ after the last meal ${ }^{7}$. Briefly, ileal digesta were collected and immediately frozen and stored at $-20^{\circ} \mathrm{C}$ before being freeze-dried and ground ( $1 \mathrm{~mm}$ mesh screen). Tissue samples $(3 \mathrm{~cm}$ in length) of distal ileum were collected, open longitudinally and washed three times in distilled water $\left(4^{\circ} \mathrm{C}\right)$ and immediately frozen in liquid nitrogen. Later, the tissue samples were thawed on ice and homogenized in icecold saline $(0.9 \% \mathrm{NaCl} ; 40 \mathrm{mg}$ tissue $/ \mathrm{ml})$. Soluble protein of ileal digesta was extracted in borate buffer $\left(0 \cdot 1 \mathrm{M}-\mathrm{H}_{3} \mathrm{BO}_{3}\right.$, $0.15 \mathrm{M}-\mathrm{NaCl}, \mathrm{pH} 8.0)$ for $1 \mathrm{~h}$ at $4^{\circ} \mathrm{C}(300 \mathrm{mg}$ digesta/ml buffer). Then, the tissue and digesta preparations were centrifuged at $12000 \mathrm{~g}$ for $10 \mathrm{~min}$ at $4^{\circ} \mathrm{C}$. Supernatants were fractionated in aliquots and stored at $-40^{\circ} \mathrm{C}$ until electrophoresis and Western blotting analysis. Soluble protein concentration in digesta and mucosa preparations was measured with the Folin phenol reagent ${ }^{17}$.

\section{Production of hyperimmune plasmas against phaseolin types}

Hyperimmune plasmas were prepared in New Zealand White rabbits by injecting an emulsion of SDS-PAGE gel bands ${ }^{18}$
Table 1. Ingredients and analytical composition of the experimental diets

\begin{tabular}{|c|c|c|}
\hline & \multicolumn{2}{|c|}{ Diet $(g / k g ~ D M)^{\star}$} \\
\hline & C & $\mathrm{S}, \mathrm{T}$ or $\mathrm{I}$ \\
\hline \multicolumn{3}{|l|}{ Ingredients } \\
\hline Casein† & 118 & 54 \\
\hline Phaseolin & 0 & 52 \\
\hline Starch & 582 & 594 \\
\hline Sucrose & 100 & 100 \\
\hline Ground rice hulls & 80 & 80 \\
\hline Vegetal oilł & 60 & 60 \\
\hline Vitamins-trace elements§ & 10 & 10 \\
\hline Sodium chloride & 10 & 10 \\
\hline Calcium carbonate & 15 & 15 \\
\hline Calcium phosphate & 25 & 25 \\
\hline \multicolumn{3}{|l|}{ Analysis } \\
\hline $\mathrm{DM}(\mathrm{g} / \mathrm{kg})$ & 910 & 900 \\
\hline Crude protein $(\mathrm{N} \times 6.25)$ & 109 & 111 \\
\hline Ether extract & 65 & 65 \\
\hline Ash & 71 & 66 \\
\hline Neutral detergent fibre & 63 & 68 \\
\hline Gross energy (MJ/kg DM) & $16 \cdot 3$ & $16 \cdot 9$ \\
\hline
\end{tabular}

* Diets: C, casein control; S, T and I, diets with Sanilac, Tendergreen and Inca phaseolins (unheated or heated) providing $500 \mathrm{~g} / \mathrm{kg}$ of the total dietary protein. †Casein was supplemented with $30 \mathrm{~g}$ DL-methionine $/ \mathrm{kg}$ DM casein. ¥ Soyabean oil-sunflower oil (1:1).

$\S$ Mineral and vitamin mixture supplied per $\mathrm{kg}$ diet (control and experimental): $7.5 \mathrm{mg}$ vitamin $\mathrm{A} ; 0.2 \mathrm{mg}$ vitamin $\mathrm{D}_{3} ; 15 \mathrm{mg}$ vitamin $\mathrm{E} ; 6 \mathrm{mg}$ vitamin $\mathrm{K} ; 10 \mathrm{mg}$ vitamin $B_{2} ; 35 \mathrm{mg}$ calcium pantothenate; $75 \mathrm{mg}$ niacin; $2.5 \mathrm{mg}$ vitamin $\mathrm{B}_{6} ; 0.05 \mathrm{mg}$ vitamin $B_{12} ; 0.05 \mathrm{mg}$ biotin; $200 \mathrm{mg}$ choline; $150 \mathrm{mg} \mathrm{Mn} ; 500 \mathrm{mg} \mathrm{Zn} ; 40 \mathrm{mg} \mathrm{Cu}$, $200 \mathrm{mg} \mathrm{Fe} ; 2 \mathrm{mg} \mathrm{I} ; 0.5 \mathrm{mg} \mathrm{Se}, 1 \mathrm{mg}$ Co.

containing one type of phaseolin (S, T or I) and Freund's complete or incomplete adjuvant (F-5881 and F-5506 respectively; Sigma Chemical Co., St Louis, MO, USA). Immunization was conducted with approximately $300 \mu \mathrm{g}$ pure phaseolin at each of the three injections as reported for other legume grain globulins ${ }^{15}$. Since a high cross-immunoreactivity was found between phaseolin types, a mixture of hyperimmune plasmas against $\mathrm{S}$, T and I phaseolin was prepared and used for Western blotting in the present study.

\section{SDS-PAGE and Western blotting}

SDS-PAGE electrophoresis and Western blotting analysis were conducted as previously described ${ }^{15}$. Protein loads were 5 and $30 \mu \mathrm{g} / \mathrm{well}$ for pure protein (phaseolin and casein) and for ileal samples (digesta and mucosa), respectively. Molecular weight (MW) standards (14.4-97.0 kDa; 17-0446-01; Pharmacia, Uppsala, Sweden) were also loaded in a separate well on each gel. After electrophoresis, proteins in one gel were stained by Coomassie brilliant blue while proteins from a similar gel run simultaneously in the same device were electro-transferred to nitrocellulose membranes ${ }^{15}$.

\section{Densitometry measurements}

The densitometry measurements were made according to Salgado et $a l .{ }^{15}$. The gels with Coomassie blue-stained proteins and the membranes were scanned using a phosphor imager (Quantum Appligene, version 2.03; Illkirch, France). Staining density was measured horizontally for each band of interest using image analysis (Image-QuaNT, version 4.2a; Molecular 
Dynamics, Sunnyvale, CA, USA), in order to generate statistical data for specific bands. These staining densities are homogenous with concentrations since the same amounts of soluble protein for a given type of sample were deposited at the top of the lanes. The MW of each protein band detected visually was determined by linear regression using the MW standards. Densitometry was carried out in both phaseolin peptides and endogenous proteins of digesta samples, while it focused only on phaseolin peptides in the case of ileal tissues.

\section{In-gel trypsin digestion and $M S$}

In-gel digestion with trypsin was carried out according to a method $^{19}$ slightly modified. Briefly, most bands detected visually in SDS-PAGE gels of digesta and mucosa were excised, washed in acetonitrile-0.05 $\mathrm{M}$-ammonium bicarbonate $(1: 1)$ and dried in a Speed Vac concentrator (Bioblock, Illkirch, France). Proteins in the sliced gels were reduced with dithiothreitol at $60^{\circ} \mathrm{C}$ for $40 \mathrm{~min}$ and alkylated by iodoacetamide for 30 min in the dark. Digestion by trypsin (sequencing grade; Promega, Charbonnières, France) was carried out at $0.5 \mu \mathrm{g} /$ sample, in $25 \mu \mathrm{l} 0.05 \mathrm{M}$-ammonium bicarbonate, at $\mathrm{pH} 8.0$ for $18 \mathrm{~h}$ at $37^{\circ} \mathrm{C}$. The reaction was stopped by adding $2 \mu \mathrm{l}$ $5 \%$ trifluoroacetic acid (v/v; Pierce, Touzart \& Matignon, Vitry sur Seine, France). The supernatant was analysed by means of matrix-assisted laser desorption ionization-quadrupole time-of-flight MS. Collected peptides $(1 \mu \mathrm{l})$ were deposited on to the matrix-assisted laser desorption ionization target plate and $1 \mu \mathrm{l} \alpha$-cyano-4-hydroxy cinnamic acid matrix at $10 \mathrm{~g} / \mathrm{l}$ diluted $1: 5(\mathrm{v} / \mathrm{v})$ with solution containing $0.1 \%$ trifluoroacetic acid (v/v) and $70 \%$ acetonitrile (v/v) was added on to the spots dried on the target plate. The plate was introduced into the quadrupole time-of-flight mass spectrometer (Qstar XL; Applied Biosystems, Framingham, MA, USA). oMALDI Xpert2.0 software was used for the matrix-assisted laser desorption ionization MS and MS-MS experiments. Samples were ionized with a laser beam $(\lambda=337 \mathrm{~nm})$ and each spectrum was an average of 250-500 laser shots. The more representative monocharged ions were automatically submitted to fragmentation with energy of collision of near $0.05 \mathrm{eV} / \mathrm{Da}^{20}$. Typically, oMALDI Xpert2.0 software treated each sample well individually and generated an MS peak list. This list was submitted for a peptide mass fingerprinting search and used as a 'survey scan' to determine peptide precursors for MS/MS acquisition. All MS and MS-MS data were then used with Modular Approach to Software Construction Operation and Test software (MASCOT, version 1.9) for search into several databases such as Swiss Prot or the National Centre for Biotechnology Information to identify the proteins present in each gel band. The quality of peptide identification was reported using molecular weight search scoring ${ }^{21}$.

\section{Statistical analysis}

Since there were not enough tracks on each gel, only samples corresponding to unheated casein control were analysed together with those coming from phaseolin-fed rats. Indeed, both unheated and heated casein displayed similar in vivo digestibilities ${ }^{7}$. Thus, two separate ANOVA of the data were conducted using the General Linear Model procedure of Statistical Analysis Systems statistical software package version 8.0 (SAS Institute Inc., Cary, NC, USA). In the first one, effects of phaseolin type, heat treatment and their interaction were tested. When the $F$ value of the ANOVA was significant $(P<0.05)$, the means were compared using Duncan's multiple range test ${ }^{22}$. A second ANOVA was conducted to compare data between casein control and heated phaseolins. Such treatments were usually not different $(P>0 \cdot 10)$ and data for unheated casein are provided in the tables for information only.

\section{Results}

No particular problems were encountered with the rats. They consumed on average 9.2 (SD 1) g food/d with no significant difference among treatments $(P=0 \cdot 213)$.

\section{Protein sources}

$S D S-P A G E$. The electrophoresis patterns under reducing condition of casein and $\mathrm{S}, \mathrm{T}$ and $\mathrm{I}$ phaseolin types in native form are presented in Fig. 1. Casein displayed two bands with MW between $29-31 \mathrm{kDa}$ and $31 \cdot 5-33 \mathrm{kDa}$. For the phaseolin types, the subunits were observed in MW ranging from 43.1 to $51.5 \mathrm{kDa}$, three subunits being visible for $\mathrm{T}$ phaseolin and two subunits for $\mathrm{S}$ and I phaseolins (Table 2).

Western blotting. The antibodies raised against phaseolin did not label casein but recognized all the polypeptide subunits of S, T and I phaseolin types (Fig. 1).

$M S$. MS identification showed that $\mathrm{S}$ and $\mathrm{T}$ phaseolins comprised subunits originating from $\alpha$ and $\beta$ precursors (Table 2). In addition, the third band of $\mathrm{T}$ phaseolin and the two bands of I phaseolin originated from $\beta$ precursor.

\section{Protein patterns in ileal digesta}

SDS-PAGE. Representative SDS-PAGE gels of soluble proteins from digesta collected at the end of the small intestine

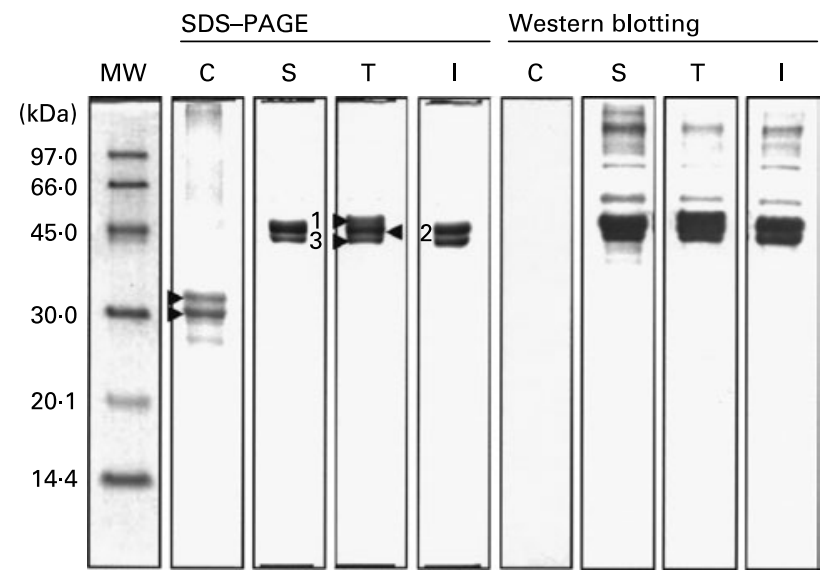

Fig. 1. SDS-PAGE and Western blotting analysis of casein (C) and Sanilac (S), Tendergreen (T) and Inca (I) phaseolins. Molecular weight (MW) markers are indicated. $\downarrow$, bands characterized by MS in Table 2 . 
Table 2. Molecular weight search (MOWSE) score for MS identification of protein bands in pure unheated phaseolin

\begin{tabular}{|c|c|c|c|c|}
\hline \multicolumn{3}{|c|}{ Sample identification } & \multicolumn{2}{|c|}{ MOWSE score* } \\
\hline \multirow[b]{2}{*}{ Band $†$} & \multirow[b]{2}{*}{ Protein } & \multirow[b]{2}{*}{ MW (kDa) } & \multicolumn{2}{|c|}{ Precursor type from database } \\
\hline & & & Phaseolin $\alpha(49 \cdot 2 \mathrm{kDa})$ & Phaseolin $\beta$ (47.5 kDa) \\
\hline 1 & $\mathrm{~S}$ & $45 \cdot 6-50 \cdot 1$ & $143 \ddagger$ & 132 \\
\hline 2 & $\mathrm{~s}$ & $44 \cdot 1-45 \cdot 0$ & 135 & $158 \ddagger$ \\
\hline 1 & $\mathrm{~T}$ & $46.9-51.5$ & $123 \ddagger$ & 102 \\
\hline 2 & $\mathrm{~T}$ & $44 \cdot 7-45 \cdot 5$ & 112 & $172 \ddagger$ \\
\hline 3 & $\mathrm{~T}$ & $43 \cdot 7-44 \cdot 1$ & 113 & $146 \ddagger$ \\
\hline 1 & 1 & $46 \cdot 7-48 \cdot 9$ & 97 & $174 \ddagger$ \\
\hline 2 & 1 & $43 \cdot 1-44 \cdot 4$ & 94 & $154 \ddagger$ \\
\hline
\end{tabular}

I, Inca phaseolin; S, Sanilac phaseolin; T, Tendergreen phaseolin.

${ }^{*}$ MOWSE score $\leq 65$ is not significant $(P>0.05)$ for MS identification ${ }^{21}$

tIdentification of bands as shown in Fig. 1.

$\ddagger$ Values confirmed by MS-MS.

are shown in Fig. 2(A). For the ileal contents from rats fed casein, few faint bands were observed. By contrast, in rats fed diets containing unheated phaseolins, strong bands with MW between 18 and $24 \mathrm{kDa}$ appeared, together with other fainter bands. After thermal treatment, most of these bands disappeared and the remaining visible faint bands were similar to those observed with the control diet.

Densities tended $(P=0 \cdot 10)$ to be lower with unheated I phaseolin than with the $\mathrm{S}$ and T types for bands at MW 26.5-28 and $31.5-33 \mathrm{kDa}$ (Table 3). No other difference due to phaseolin type was seen. Heat treatment was almost always highly significant $(P<0.001)$ in reducing the intensity of all the bands (Fig. 2(A)).

Western blotting. The anti-phaseolin antibodies did not reveal any band in the digesta of rats fed with the casein diet (Fig. 2(B)). By contrast, in the digesta of rats fed unheated phaseolins, a strong immuno-labelling was present at MW ranges of intact phaseolin $(44-54 \mathrm{kDa})$ and phaseolin fragments $(19-24 \mathrm{kDa})$. These bands were seen in SDS-PAGE too. However, all the immuno-reactivity disappeared when digesta from rats fed heated phaseolins were considered. Intensity of the bands was lower at MW $47-50 \mathrm{kDa} \quad(P=0.048)$ and $44-46.5 \mathrm{kDa} \quad(P=0.112)$ in digesta of rats fed diets with unheated $\mathrm{T}$ and $\mathrm{I}$ phaseolin as compared to $S$ phaseolin (Table 3). Intensity of the band at MW $19-21.5 \mathrm{kDa}$ was higher with unheated $\mathrm{T}$ phaseolin, as compared to $\mathrm{S}$ and I types $(P=0.026)$. In all cases, thermal treatment reduced band intensities $(P<0.01)$ with no differences remaining between phaseolin types $(P>0.05)$.

MS. Bands of ileal digesta of untreated phaseolin at MW $18-18.5$ and $22-24 \mathrm{kDa}$ for $\mathrm{S}$ phaseolin and $22-24 \mathrm{kDa}$ for $\mathrm{T}$ phaseolin were shown to originate from $\alpha$ precursor. The rest of the digesta bands in the range of 15.5 to $24 \mathrm{kDa}$ for $\mathrm{S}, \mathrm{T}$ and I phaseolins were identified as originating from $\beta$ precursor (Table 4). A smaller polypeptide at MW $11 \mathrm{kDa}$ ( $Y$ in Table 4 and Fig. 2(A)) visible with the $\mathrm{T}$ phaseolin diet was from $\beta$ precursor too. On the other hand, three proteins at MW 55-61, 31 ( $X$ in Table 4 and Fig. 2(A)) and $26-28 \mathrm{kDa}$ were identified as host enzymes, namely pancreatic $\alpha$-amylase for the first two bands, and anionic trypsin I for the third band.
Protein patterns of the ileal mucosa

SDS-PAGE. The electrophoresis of soluble ileal mucosa proteins are presented in Fig. 3(A). In all tracks, several bands were observed. However, three different bands of MW ranging from 18.5 to $26 \mathrm{kDa}$ were detected with high intensity only in
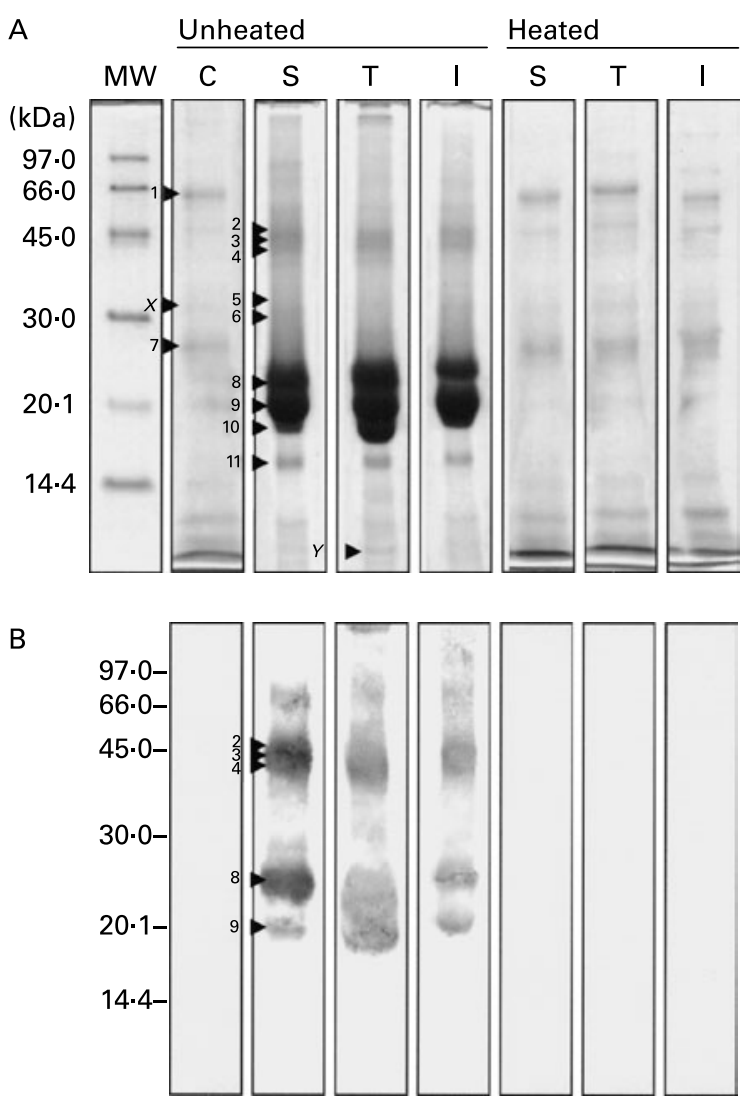

Fig. 2. SDS-PAGE (A) and Western blotting (B) analysis of ileal digesta of rats fed diets with casein (C) or Sanilac (S), Tendergreen (T) and Inca (I) phaseolins in unheated or heated form. Molecular weight (MW) markers are indicated. $\downarrow$, bands characterized by densitometry in Table 3 and by MS in Table 4 
Table 3. Densitometry analysis (arbitrary density units) of SDS-PAGE and Western blotting patterns of ileal digesta of rats fed with different types of phaseolin either unheated or heated, and casein $(C)$ as control (five rats per treatment)

\begin{tabular}{|c|c|c|c|c|c|c|c|c|c|c|c|c|}
\hline \multirow{2}{*}{$\begin{array}{l}\text { Protein band } \\
\text { No. }\end{array}$} & \multirow[b]{2}{*}{ MW (kDa) } & \multirow[b]{2}{*}{$\mathrm{C}^{*}$} & \multicolumn{3}{|c|}{ Diet, phaseolin unheated } & \multicolumn{3}{|c|}{ Diet, phaseolin heated } & \multirow[b]{2}{*}{ RSD } & \multicolumn{3}{|c|}{$P$} \\
\hline & & & $\mathrm{S}$ & $\mathrm{T}$ & I & S & $\mathrm{T}$ & 1 & & Phas & Heat & $\mathrm{Ph} \times \mathrm{H} \dagger$ \\
\hline \multicolumn{13}{|l|}{ SDS-PAGE } \\
\hline 1 & $55 \cdot 0-61 \cdot 0$ & $10 \cdot 9$ & $9 \cdot 6$ & $9 \cdot 7$ & $7 \cdot 1$ & $6 \cdot 8$ & $6 \cdot 4$ & $6 \cdot 1$ & $2 \cdot 4$ & 0.330 & 0.028 & 0.583 \\
\hline 2 & $46 \cdot 9-51 \cdot 5$ & $5 \cdot 3$ & 11.9 & $11 \cdot 2$ & $8 \cdot 8$ & $3 \cdot 8$ & $4 \cdot 3$ & $5 \cdot 1$ & $2 \cdot 0$ & 0.614 & 0.001 & 0.110 \\
\hline 3 & $44 \cdot 7-45 \cdot 5$ & $5 \cdot 9$ & $14 \cdot 1$ & $12 \cdot 7$ & $10 \cdot 9$ & $3 \cdot 8$ & $4 \cdot 7$ & $4 \cdot 3$ & $2 \cdot 0$ & 0.412 & 0.001 & 0.238 \\
\hline 4 & $43 \cdot 7-44 \cdot 1$ & $4 \cdot 8$ & $12 \cdot 7$ & $13 \cdot 0$ & $11 \cdot 1$ & $3 \cdot 9$ & 3.9 & $4 \cdot 3$ & $1 \cdot 6$ & 0.663 & 0.001 & 0.329 \\
\hline 6 & $29 \cdot 0-31 \cdot 0$ & $5 \cdot 3$ & $13 \cdot 2$ & $14 \cdot 1$ & $10 \cdot 1$ & $5 \cdot 4$ & $5 \cdot 4$ & $5 \cdot 2$ & $2 \cdot 0$ & 0.132 & 0.001 & 0.172 \\
\hline 7 & $26 \cdot 5-28 \cdot 0$ & $7 \cdot 3$ & $17 \cdot 1$ & $18 \cdot 6$ & $14 \cdot 3$ & 8.7 & $8 \cdot 2$ & 8.9 & $2 \cdot 1$ & 0.254 & 0.001 & 0.095 \\
\hline 8 & $22 \cdot 0-24 \cdot 0$ & $4 \cdot 6$ & $27 \cdot 5$ & $26 \cdot 9$ & $26 \cdot 1$ & 4.4 & 5.9 & 4.9 & $1 \cdot 3$ & 0.376 & 0.001 & 0.291 \\
\hline 9 & $19 \cdot 0-21 \cdot 5$ & 4.5 & $29 \cdot 2$ & $29 \cdot 1$ & $28 \cdot 0$ & $2 \cdot 8$ & $5 \cdot 0$ & 3.9 & $1 \cdot 2$ & 0.156 & 0.001 & 0.175 \\
\hline 10 & $18 \cdot 0-18 \cdot 5$ & $3 \cdot 2$ & $25 \cdot 8$ & $27 \cdot 8$ & $27 \cdot 7$ & $3 \cdot 2$ & $3 \cdot 8$ & $3 \cdot 4$ & 1.5 & 0.226 & 0.001 & 0.497 \\
\hline 11 & $15 \cdot 5-16 \cdot 5$ & $4 \cdot 8$ & $11 \cdot 3$ & $10 \cdot 4$ & $9 \cdot 8$ & $3 \cdot 8$ & 3.9 & $4 \cdot 3$ & 1.4 & 0.773 & 0.001 & 0.451 \\
\hline \multicolumn{13}{|c|}{ Western blotting } \\
\hline 2 & $51 \cdot 0-54 \cdot 0$ & 3 & - & 28 & - & - & 7 & - & 6 & - & 0.025 & - \\
\hline 4 & $44 \cdot 0-46 \cdot 5$ & 5 & 120 & 95 & 56 & 1 & 2 & 0 & 26 & 0.097 & 0.001 & 0.112 \\
\hline 8 & $22 \cdot 0-24 \cdot 0$ & 1 & 84 & 92 & 95 & 0 & 0 & 0 & 16 & 0.806 & 0.001 & 0.811 \\
\hline 9 & $19 \cdot 0-21 \cdot 5$ & 2 & $83^{b}$ & $126^{a}$ & $79^{b}$ & $0^{c}$ & $0^{c}$ & $4^{c}$ & 16 & 0.026 & 0.001 & 0.026 \\
\hline
\end{tabular}

I, Inca phaseolin; Phas, phaseolin type; RSD, residual standard deviation; S, Sanilac phaseolin; T, Tendergreen phaseolin.

a,b,c Values within a row with unlike superscript letters were significantly different $(P<0.05)$.

* Control digesta from rats fed the unheated casein diet were not taken into account in the statistical analysis. They were separately compared with the data of heated phaseolins and revealed no significant differences $(P>0.05)$.

†Phaseolin type by heat interaction.

rats fed diets containing unheated phaseolins, regardless of phaseolin type (Fig. 3(A)). Density of the first two bands $(P<0.001)$ and of the third band $(P=0.067)$ (Table 5) was reduced in rats fed heat-treated phaseolins.

Western blotting. The three SDS-PAGE bands described above and another one at MW $48-52.5 \mathrm{kDa}$ were revealed by Western blotting only in digesta of rats fed diets with unheated phaseolin (Fig. 3(B)). Densitometry indicated an influence of heat treatment $(P<0.001)$ for the bands at MW $48-52.5$ and $26-27 \mathrm{kDa}$ (Table 5). The intensity of the band at MW $20 \cdot 5-21.5 \mathrm{kDa}$ was higher in the mucosa of rats fed unheated $\mathrm{T}$ and I phaseolin, as compared to $\mathrm{S}$ phaseolin $(P<0.001)$. Finally, the band at MW $22.5-24.5 \mathrm{kDa}$ was not consistently revealed by Western blotting.

Table 4. Molecular weight search (MOWSE) score for MS identification of protein bands in intestinal digesta of rats fed with a diet containing casein or a mixture of unheated casein and phaseolins

\begin{tabular}{|c|c|c|c|c|c|}
\hline \multirow{3}{*}{$\begin{array}{l}\text { Sample identification } \\
\text { Band† }\end{array}$} & \multirow[b]{3}{*}{ Dietł } & \multirow[b]{3}{*}{ MW (kDa) } & \multicolumn{3}{|c|}{ MOWSE score* } \\
\hline & & & \multicolumn{2}{|c|}{ Precursor type from database } & \multirow[b]{2}{*}{ Others } \\
\hline & & & Phaseolin $\alpha$ (49.2 kDa) & Phaseolin $\beta$ (47.5 kDa) & \\
\hline 1 & Cas & $55 \cdot 0-61 \cdot 0$ & - & - & $67 \S \|$ \\
\hline 7 & Cas & $26 \cdot 5-28 \cdot 0$ & - & - & $61 \S \rrbracket$ \\
\hline 8 & $\mathrm{~S}$ & $22 \cdot 0-24 \cdot 0$ & $86 \S$ & 61 & - \\
\hline 9 & $\mathrm{~S}$ & $19 \cdot 0-21 \cdot 5$ & 72 & $82 \S$ & - \\
\hline 10 & $\mathrm{~S}$ & $18 \cdot 0-18 \cdot 5$ & $63 \S$ & - & - \\
\hline 11 & $S$ & $15 \cdot 5-16 \cdot 5$ & 75 & $87 \S$ & - \\
\hline 8 & $\mathrm{~T}$ & $22 \cdot 0-24 \cdot 0$ & $83 \S$ & 70 & - \\
\hline 9 & $\mathrm{~T}$ & $19 \cdot 0-21 \cdot 5$ & 54 & $82 \S$ & - \\
\hline 10 & $\mathrm{~T}$ & $18 \cdot 0-18 \cdot 5$ & 112 & $113 \S$ & - \\
\hline 8 & 1 & $22 \cdot 0-24 \cdot 0$ & 105 & $109 \S$ & - \\
\hline 9 & I & $19 \cdot 0-21 \cdot 5$ & 60 & $97 \S$ & - \\
\hline 10 & I & $18 \cdot 0-18 \cdot 5$ & 56 & $80 \S$ & - \\
\hline$X^{\star *}$ & Cas & $31 \cdot 0$ & - & - & $77 \S \|$ \\
\hline$Y^{\star *}$ & $\mathrm{~T}$ & $11 \cdot 0$ & 91 & $92 \S$ & - \\
\hline
\end{tabular}

* MOWSE score $\leq 65$ is not significant $(P>0.05)$ for MS identification ${ }^{21}$

†Identification of bands on the SDS-PAGE of ileal digesta as shown in Fig. 2(A).

¥lleal digesta of rats fed diets differing in protein sources: Cas, casein; I, Inca phaseolin; S, Sanilac phaseolin; T, Tendergreen phaseolin.

§Values confirmed by MS-MS.

\| Pancreatic $\alpha$-amylase precursor, MW 57.8 kDa.

I Anionic trypsin I precursor, MW $26 \mathrm{kDa}$.

* Bands not visually distinguishable in all the rats. 
A

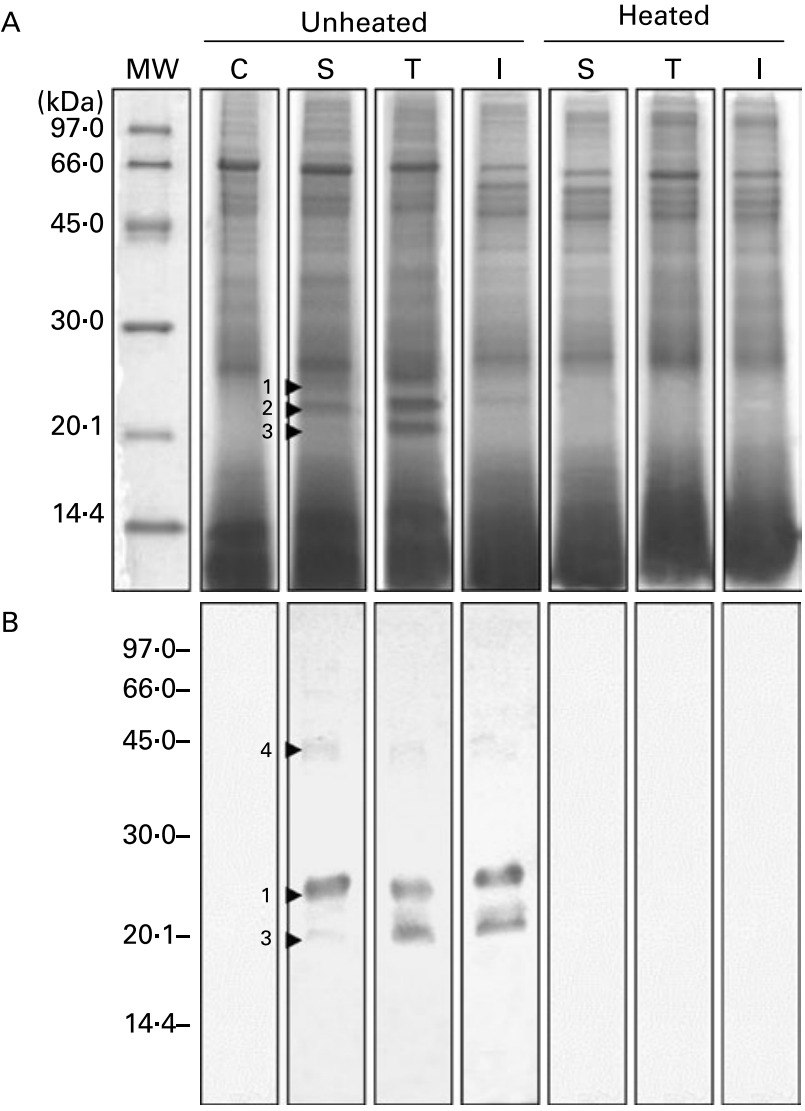

Fig. 3. SDS-PAGE (A) and Western blotting (B) analysis of ileal mucosa of rats fed with casein (C) or Sanilac (S), Tendergreen (T) and Inca (I) phaseolins in unheated or heated form. Molecular weight (MW) markers are indicated. $>$, bands characterized by densitometry in Table 5 and by MS in Table 6.

$M S$. Most bands of interest in ileal mucosa were shown to be of phaseolin origin (Table 6). However, the patterns substantially differed between phaseolin types. Bands in a decreasing order of MW were from $\alpha, \alpha$ and $\beta$ precursors for S phaseolin and $\alpha, \beta$ and $\alpha$ for T phaseolin. In the case of I phaseolin, one band was identified as coming from the phaseolin $\beta$ precursor while the other one was not phaseolin.

\section{Discussion}

The present data provide evidence for differences in digestion among phaseolin types and add some light on the molecular origin of various protein bands in the ileal digesta and mucosa.

\section{Biochemistry of phaseolin types}

The T phaseolin has three bands at MW 53, 47 and $43 \mathrm{kDa}^{23}$. MS identification of phaseolin subunits confirmed differences in the patterns of precursors among phaseolin types: $\alpha$ and $\beta$ for $S$ phaseolin, $\alpha, \beta$ and $\beta$ for T phaseolin, and $\beta$ and $\beta$ for I phaseolin. Phaseolin $\alpha$ and $\beta$ precursors are known for their high sequence homology. But, they still differ in some amino acids, carbohydrates, phosphate binding sites and contents in solvent molecules ${ }^{24,25}$.

The sequence of $\alpha$ phaseolin genes showed higher similarity between the $S$ and $T$ phaseolin types than $\beta$ phaseolin genes ${ }^{9}$. Moreover, the sequences between $\alpha$ and $\beta$ phaseolin genes were divergent. The present observations suggested the divergence between $\mathrm{S}$ and $\mathrm{T}$ phaseolin types ${ }^{9}$. The gene sequence analysis of one subunit of I phaseolin revealed identical sequences with one subunit for $\mathrm{S}$ and $\mathrm{T}$ phaseolins ${ }^{26}$. These authors suggested I phaseolin to be an ancestral phaseolin type. The analysis showed that every phaseolin has a different profile of subunit precursors. Slight differences in the tertiary structure of the monomer cause distinct quaternary structure $^{27}$, which could be the basis for differences in intestinal digestion.

\section{Phaseolin digestion}

Undigested phaseolin polypeptides with MW ranging from 18 to $24 \mathrm{kDa}$ were detected and identified in the rat ileal digesta by both Western blotting and MS. Similar undigested polypeptides were reported in previous in vitro and in vivo studies ${ }^{5,6,13}$. However, until this work, no evidence was available in the literature about the molecular origin of undigested phaseolin polypeptides. Trypsin cleaves native phaseolin in vitro into nearly two halves of MW 21.3 and $24.7 \mathrm{kDa}^{5}$.

Some differences among phaseolin types were found in digestion in the small intestine. Intact polypeptides of MW

Table 5. Densitometry analysis (arbitrary density units) of SDS-PAGE and Western blotting patterns of ileal mucosa of rats fed with different types of phaseolin either unheated or heated, and casein (C) as control (five rats per treatment)

\begin{tabular}{|c|c|c|c|c|c|c|c|c|c|c|c|c|}
\hline \multirow{2}{*}{$\begin{array}{l}\text { Protein band } \\
\text { No. }\end{array}$} & \multirow[b]{2}{*}{ MW (kDa) } & \multirow[b]{2}{*}{$C^{*}$} & \multicolumn{3}{|c|}{ Diet, phaseolin unheated } & \multicolumn{3}{|c|}{ Diet, phaseolin heated } & \multirow[b]{2}{*}{ RSD } & \multicolumn{3}{|c|}{$P$} \\
\hline & & & $\mathrm{s}$ & $\mathrm{T}$ & 1 & $\mathrm{~s}$ & $\mathrm{~T}$ & 1 & & Phas & Heat & $\mathrm{Ph} \times \mathrm{H} \dagger$ \\
\hline \multicolumn{13}{|l|}{ SDS-PAGE } \\
\hline 1 & $26 \cdot 0-27 \cdot 0$ & $13 \cdot 2$ & $20 \cdot 1$ & 21.4 & $17 \cdot 9$ & $13 \cdot 1$ & $12 \cdot 3$ & $12 \cdot 7$ & $3 \cdot 4$ & 0.609 & 0.001 & 0.508 \\
\hline 2 & $22 \cdot 5-24.5$ & $10 \cdot 6$ & $16 \cdot 2$ & $19 \cdot 0$ & $16 \cdot 5$ & $11 \cdot 7$ & 11.5 & $12 \cdot 1$ & $3 \cdot 3$ & 0.707 & 0.001 & 0.581 \\
\hline 3 & $20 \cdot 5-21 \cdot 5$ & $10 \cdot 0$ & $12 \cdot 2$ & 15.4 & $13 \cdot 6$ & 11.9 & $10 \cdot 9$ & 11.4 & $2 \cdot 9$ & 0.763 & 0.067 & 0.395 \\
\hline \multicolumn{13}{|c|}{ Western blotting } \\
\hline 4 & $48 \cdot 0-52 \cdot 5$ & 0.0 & $6 \cdot 6$ & 4.8 & 3.4 & 0.0 & 0.2 & 0.1 & $2 \cdot 2$ & 0.411 & 0.001 & 0.362 \\
\hline 1 & $26 \cdot 0-27 \cdot 0$ & 0.0 & $22 \cdot 2$ & $30 \cdot 0$ & $28 \cdot 3$ & 0.2 & $0 \cdot 1$ & 0.1 & $5 \cdot 0$ & 0.334 & 0.001 & 0.322 \\
\hline 3 & $20.5-21.5$ & 0.0 & $4.6^{\mathrm{b}}$ & $17 \cdot 7^{\mathrm{a}}$ & $18 \cdot 0^{\mathrm{a}}$ & $0.0^{\mathrm{c}}$ & $0.0^{c}$ & $0.0^{\mathrm{c}}$ & 1.4 & 0.001 & 0.001 & 0.001 \\
\hline
\end{tabular}

I, Inca phaseolin; Phas, phaseolin type; RSD, residual standard deviation; S, Sanilac phaseolin; T, Tendergreen phaseolin.

a,b,c Values within a row with unlike superscript letters were significantly different $(P<0.05)$.

* Control digesta from rats fed the unheated casein diet were not taken into account in the statistical analysis. They were separately compared with the data of heated phaseolins.

†Phaseolin type by heat interaction. 
Table 6. Molecular weight search (MOWSE) score for MS identification of protein bands in ileal mucosa of rats fed with a diet containing casein or a mixture of unheated casein and phaseolins

\begin{tabular}{|c|c|c|c|c|c|}
\hline \multicolumn{3}{|c|}{ Sample identification } & \multicolumn{3}{|c|}{ MOWSE score* } \\
\hline \multirow[b]{2}{*}{ Band $†$} & \multirow[b]{2}{*}{ Dietł } & \multirow[b]{2}{*}{ MW (kDa) } & \multicolumn{2}{|c|}{ Precursor type from database } & \multirow[b]{2}{*}{ Others } \\
\hline & & & Phaseolin $\alpha(49 \cdot 2 \mathrm{kDa})$ & Phaseolin $\beta$ (47.5 kDa) & \\
\hline 1 & $\mathrm{~S}$ & $26 \cdot 0-27 \cdot 0$ & $93 \S$ & 84 & - \\
\hline 2 & $\mathrm{~S}$ & $22 \cdot 5-24 \cdot 5$ & $108 \S$ & 107 & - \\
\hline 3 & $\mathrm{~S}$ & $20 \cdot 5-21.5$ & 94 & $103 \S$ & - \\
\hline 1 & $\mathrm{~T}$ & $26 \cdot 0-27 \cdot 0$ & $99 \S$ & 93 & - \\
\hline 2 & $\mathrm{~T}$ & $22 \cdot 5-24.5$ & 89 & $116 \S$ & - \\
\hline 3 & $\mathrm{~T}$ & $20 \cdot 5-21.5$ & $170 \S$ & 163 & - \\
\hline 1 & 1 & $26 \cdot 0-27 \cdot 0$ & - & - & $13 \|$ \\
\hline 2 & I & $22 \cdot 5-24.5$ & 66 & $86 \S$ & - \\
\hline
\end{tabular}

${ }^{*}$ MOWSE score $\leq 65$ is not significant $(P>0.05)$ for MS identification ${ }^{21}$

t Identification of bands on the SDS-PAGE of ileal mucosa as shown in Fig. 3(A).

$\ddagger$ Ileal mucosa of rats fed diets differing in protein sources: Cas, casein; I, Inca phaseolin; S, Sanilac phaseolin; T, Tendergreen phaseolin.

$\S$ Values confirmed by MS-MS.

|| Cytokeratin 10.

$44 \cdot 1-45$ and $45 \cdot 6-50 \cdot 1 \mathrm{kDa}$ from untreated $\mathrm{S}$ phaseolin reached the ileum in concentrations higher than for $\mathrm{T}$ and $\mathrm{I}$ phaseolins. Also the polypeptide of MW 19-21.5 kDa was apparently less digested in the case of $\mathrm{T}$ phaseolin compared to $\mathrm{S}$ and I phaseolins, despite a common $\beta$ origin. However, it is important to consider that $\mathrm{T}$ phaseolin has three subunits. The difference in $\beta$ phaseolin precursors between phaseolin types mentioned earlier could explain the differences in $\beta$ phaseolin digestion. A study in pigs fed diets containing common beans with $\mathrm{S}$ and $\mathrm{T}$ phaseolin types reported an ileal digestibility value higher for $\mathrm{S}$ phaseolin $(57 \%)$ as compared to $\mathrm{T}$ phaseolin $(36 \%)^{12}$. Such discrepancies may arise from the use of whole beans in the study by Begbie and Ross ${ }^{12}$ as compared to the present study with purified phaseolin. Also, differences due to animal species and common bean composition cannot be excluded. Two publications ${ }^{6,28}$ suggest slight differences between phaseolin types after in vitro proteolysis, but these studies based on SDS-PAGE were only qualitative.

\section{Phaseolin and intestinal endogenous protein components}

Two endogenous proteins were identified in the ileal digesta: pancreatic $\alpha$-amylase as a nearly intact molecule at MW $55-61 \mathrm{kDa}$ and a fainter digestion fragment at $31 \mathrm{kDa}$, and anionic trypsin I at MW $26 \cdot 5-28 \mathrm{kDa}$. These two enzymes were also identified with higher concentration and daily flow at the ileum of pigs fed various legume grains as compared to casein as the control ${ }^{14,15}$. The lower number of endogenous bands revealed by SDS-PAGE here could be due to a lower endogenous protein loss in rats as compared to pigs ${ }^{29}$. In the present study, the ileal concentration of intact pancreatic $\alpha$-amylase was lower with diets containing heated phaseolin, irrespective of phaseolin type. The trypsin concentration tended to be lower with unheated I phaseolin than with the $\mathrm{S}$ or $\mathrm{T}$ types, emphasizing the idea that I phaseolin is more susceptible to digestion. Intestinal trypsin concentration and flow increase with protein resistance to digestion as shown by guanidination of casein in rats ${ }^{30}$. Santoro et al. ${ }^{13}$ have hypothesized that native phaseolin remnants exert a secretagogue activity on the small intestine epithelium (e.g. cell shedding, digestive enzymes, serum proteins, mucus production). Despite this possible secretagogue activity, little effects on small intestine histomorphology were observed in rats fed diets containing unheated phaseolin ${ }^{7}$.

\section{Thermal treatment and phaseolin digestion}

Most protein bands in the ileal digesta had intensities drastically reduced in diets containing heated phaseolin, in agreement with improved digestion of phaseolin upon thermal treatment in vivo ${ }^{2,7}$ and in vitro ${ }^{4,6,10}$. Indeed, in vitro trypsinolysis of heated phaseolin quickly generates polypeptides of MW $20-30 \mathrm{kDa}$ which are then rapidly degraded into smaller peptides. Heat treatment influences structural changes and favours enzymatic hydrolysis by decreasing the percentage of $\alpha$-helices while increasing random structures in the molecule $^{4}$. No differences between heated phaseolin types were observed here. In quantitative sequential pepsin and pancreatin in vitro hydrolysis, we found that $\mathrm{T}$ and I phaseolins had a higher degree of hydrolysis than $\mathrm{S}$ phaseolin after heat treatment $\left(71,72\right.$ and $58 \%$, respectively $\left.{ }^{10}\right)$. The reason for such discrepancies between in vivo and in vitro hydrolysis could be: (1) in vivo digestion of protein is a complex process affected not only by the chemical structure of proteins but also by the biochemistry and physiology of the digestive tract as compared to in vitro digestion ${ }^{31,32}$; (2) the accumulation of in vitro digestion products could affect the efficiency and the rate of hydrolysis ${ }^{31}$; and (3) in our SDS-PAGE conditions the peptides of low MW $(<10 \mathrm{kDa})$ produced after the hydrolysis of heated phaseolin cannot be detected.

\section{Phaseolin and intestinal mucosa}

Phaseolin fragments of MW 20.5-21.5, 22.5-24.5 and $26-27 \mathrm{kDa}$ were bound to the ileal mucosa of the rats fed untreated phaseolin, in agreement with earlier observations ${ }^{13}$. This may have resulted from the propensity of undigested phaseolin peptides to aggregate ${ }^{12}$. We also found nearly intact phaseolin types on ileal mucosa, in accordance with their presence in ileal digesta. Adsorbed peptide of MW 
$20 \cdot 5-21.5 \mathrm{kDa}$ was present in a higher concentration for $\mathrm{T}$ and I phaseolins compared to $\mathrm{S}$ phaseolin. This could have reflected the higher luminal concentration of a similar peptide of MW 19-21.5 kDa observed with T phaseolin. Reasons for differences between $\mathrm{S}$ and I phaseolins for tissue concentration of this peptide are unclear.

In conclusion, the present work highlighted the differences in the phaseolin precursor subunit composition among phaseolin types. Moreover, it provided evidence for differences between phaseolin types in protein digestion in the small intestine of rats. Improvements in phaseolin digestion upon thermal treatment were shown to result from both increased digestion of phaseolin and decreased ileal concentrations of endogenous proteins. Finally, both near-native phaseolin and undigested phaseolin peptides of $\alpha$ and $\beta$ precursor origins bound to the intestinal mucosa with apparent differences between phaseolin types. Studying a larger number of phaseolin types may help investigate the possible relationships between subunit composition, biochemistry of intestinal digestion, and nutritional value of phaseolin and common bean.

\section{Acknowledgements}

Thanks are due to the Volkswagen Foundation (Hannover, Germany), COLCIENCIAS (Bogotá, Colombia), ECOS-Nord (Université de Paris 5, France) and Conseil Régional de Bretagne (Rennes, France) for financial support.

\section{References}

1. Leterme $\mathrm{P}$ (2002) Recommendations by health organizations for pulse consumption. Br J Nutr 88, Suppl. 3, S239-S242.

2. Marquez UM \& Lajolo FM (1990) Nutritional value of cooked beans Phaseolus vulgaris and their isolated major protein fractions. J Sci Food Agric 53, 235-242.

3. Gepts P \& Bliss F (1994) Enhanced available methionine associated with higher phaseolin levels in common bean seeds. Theor Appl Genet 69, 47-53.

4. Deshpande SS \& Damodaran S (1989) Structure-digestibility relationship of legume 7S proteins. J Food Sci 54, 108-113.

5. Jivotovskaya A, Senyuk V, Rotari V, Horstmann C \& Vaintraub I (1996) Proteolysis of phaseolin in relation to its structure. J Agric Food Chem 44, 3768-3772.

6. Deshpande SS \& Nielsen SS (1987) In vitro enzymatic hydrolysis of phaseolin, the major storage protein of Phaseolus vulgaris L. J Food Sci 52, 1326-1329.

7. Montoya CA, Lallès JP, Beebe S, Montagne L, Souffrant WB \& Leterme P (2006) Influence of the Phaseolus vulgaris phaseolin level of incorporation, type and thermal treatment on gut characteristics in rats. Br J Nutr 95, 116-123.

8. Koening RL, Singh SP \& Gepts P (1990) Novel phaseolin types in wild and cultivated common bean (Phaseolus vulgaris, Fabaceae). Econ Bot 44, 50-60.

9. Kami J \& Gepts P (1994) Phaseolin nucleotide sequence diversity in Phaseolus vulgaris. Genome 37, 751-757.

10. Montoya CA, Lallès JP, Beebe S, Souffrant WB \& Leterme P (2005) Effect of the types of Phaseolus vulgaris phaseolin and thermal treatment on in vitro sequential hydrolysis by pepsin and pancreatin. In Proceedings of the Fouth International Food Legumes Research Conference, pp. 61-62 [MC Kharkwal, editor]. New Delhi: Indian Society of Genetics and Plant Breeding.

11. Fukuda T, Maruyama N, Kanazawa A, Abe A, Shimamoto Y, Hiemori M, Tsuji H, Tanisaka T \& Utsumi S (2005) Molecular analysis and physico-chemical properties of electrophoretic variants of wild soybean Glycine soja storage proteins. J Agric Food Chem 53, 3658-3665.

12. Begbie R \& Ross AW (1993) Resistance of the kidney bean reserve protein, phaseolin, to proteolysis in the porcine digestive tract. J Sci Food Agric 61, 301-307.

13. Santoro LG, Grant G \& Pusztai A (1999) In vivo degradation and stimulating effect of phaseolin on nitrogen secretion in rats. Plant Foods Hum Nutr 53, 223-236.

14. Le Gall M, Quillien L, Guéguen J, Rogniaux H \& Sève B (2005) Identification of dietary and endogenous ileal protein losses in pigs by immunoblotting and mass spectrometry. J Nutr 135, 1215-1222.

15. Salgado P, Montagne L, Freire JPB, Ferreira R, Teixeira A, Bento O, Abreu M, Toullec R \& Lallès JP (2002) Legume grains enhance ileal losses of specific endogenous serine-protease proteins in weaned pigs. J Nutr 132, 1913-1920.

16. Mrad de Osorio A \& Cardozo de Martinez C (1999) Principios basicos para el manejo de animales de laboratorio. (Basic Principles for the Handling of Laboratory Animals). Bogota: Universidad Nacional de Colombia.

17. Lowry OH, Rosebrough NJ, Farr AL \& Randall RJ (1951) Protein measurement with the Folin phenol reagent. J Biol Chem 193, 265-275.

18. Boulard CH \& Lecroisey A (1982) Specific antisera produced by direct immunization with slices of polyacrylamide gel containing small amounts of protein. J Immunol Methods 50, 221-226.

19. Shevchenko A, Wilm M, Vorm O \& Mann M (1996) Mass spectrometry sequencing of proteins from silver-stained polyacrylamide gels. Anal Chem 68, 850-858.

20. Wattenberg A, Organ AJ, Schneider K, Tyldesley R, Bordoli R \& Bateman RH (2002) Sequence dependent fragmentation of peptides generated by MALDI quadrupole time-of-flight (MALDI Q-TOF) mass spectrometry and its implications for protein identification. J Am Soc Mass Spectr 13, 772-783.

21. Pappin DJC, Hojrup P \& Bleasby AJ (1993) Rapid identification of proteins by peptide-mass fingerprinting. Curr Biol 3, $327-332$

22. Duncan DB (1955) Multiple range and multiple F-tests. Biometrics 11, 1-42.

23. Hall TC, McLeester RC \& Bliss FA (1977) Equal expression of the maternal and paternal alleles for polypeptide subunits of the major storage protein of the bean Phaseolus vulgaris L. Plant Physiol 59, 1122-1124.

24. Slightom JL, Drong RF, Klassy RC \& Hoffman LM (1985) Nucleotide sequence from phaseolin cDNA clones: the major storage proteins from Phaseolus vulgaris are encoded by two unique gene families. Nucleic Acids Res 13, 6483-6498.

25. Alli I, Gibbs BF, Okoniewska MK, Konishi Y \& Dumas F (1993) Identification and characterization of phaseolin polypeptides in a crystalline protein isolated from white kidney beans (Phaseolus vulgaris). J Agric Food Chem 41, $1830-1834$.

26. Kami J, Becerra V, Debouck DG \& Gepts P (1995) Identification of presumed ancestral DNA sequences of phaseolin in Phaseolus vulgaris. Proc Natl Acad Sci USA 92, 1101-1104.

27. Banerjee R, Das K, Ravishankar R, Suguna K, Surolia A \& Vijayan M (1996) Conformation, protein-carbohydrate interactions and a novel subunit association in the refined structure of peanut lectin-lactosa complex. J Mol Biol 259, 281-296.

28. Bollini R \& Vitale A (1981) Genetic variability in charge microheterogeneity and polypeptide composition of phaseolin, the major storage protein of Phaseolus vulgaris; and peptide maps of its three major subunits. Physiol Plant 52, 96-100.

29. Hodgkinson SM, Souffrant WB \& Moughan PJ (2003) Comparison of the enzyme-hydrolyzed casein, guanidination, and 
isotope dilution methods for determining ileal endogenous protein flow in the growing rat and pig. J Anim Sci 81, 2525-2534.

30. Hara H, Nishi T \& Kasai TA (1995) Protein less sensitive to trypsin, guanidinated casein, is a potent stimulator of exocrine pancreas in rats. Proc Soc Exp Biol Med 210, $278-284$.
31. Savoie L (1994) Digestion and absorption of food: usefulness and limitations of in vitro models. Can J Physiol Pharmacol 72, 407-414.

32. Savoie L, Agudelo RA, Gauthier SF, Marin J \& Pouliot Y (2005) In vitro determination of the release kinetics of peptides and free amino acids during the digestion of food proteins. $J$ AOAC Int 88, 935-948. 